\title{
Ethos e pathos na elaboração de vínculos: considerações sobre a construção enunciativo- discursiva dos efeitos de empatia na argumentação em colunas jornalísticas
}

DOI: http://dx.doi.org/10.21165/el.v49i1.2679

\author{
Ivani Cristina Brito Fernandes ${ }^{1}$
}

\section{Resumo}

O presente artigo tem o objetivo de identificar as principais articulações de natureza textual, retórica, enunciativa e discursiva no que se refere ao esboço de um ethos e na projeção de um efeito patêmico pretendido. Para alcançar esta finalidade, selecionamos 39 textos do colunista Antonio Prata, publicados entre os meses de setembro de 2018 e maio de 2019 no jornal Folha de S. Paulo. A base teórica que estrutura esse trabalho se caracteriza pelas noções presentes nos estudos da Argumentação, da Linguística da Enunciação e da Análise do Discurso. Por outro lado, a base metodológica que nos guiará é o Paradigma Indiciário. Como hipótese, defendemos que a estrutura éticopatêmica tem auxiliado no estabelecimento de um vínculo identitário e empático entre interlocutores em torno da construção do discurso de natureza polêmica, caracterizado pela dicotomização, polarização e desqualificação da voz do outro.

Palavras-chaves: ethos; pathos; enunciação; polêmica.

1 Universidade Federal de Santa Maria (UFSM), Santa Maria, Rio Grande do Sul, Brasil; icrisifer@gmail.com; https://orcid.org/0000-0003-4747-8100. 


\section{Ethos y pathos en la elaboración de los vínculos: consideraciones sobre la construcción enunciativo-discursiva de los efectos de empatía en la argumentación en columnas periodísticas}

\section{Resumen}

El presente artículo tiene como objetivo identificar las principales articulaciones de naturaleza textual, retórica, enunciativa y discursiva, en lo tocante al esbozo de un ethos y en la proyección de un efecto patémico pretendido. Para lograr esta finalidad, elegimos 39 textos del columnista Antonio Prata, publicados entre los meses de septiembre de 2018 y mayo de 2019, en el periódico Folha de S. Paulo. La base teórica de este trabajo se estructura por medio de las nociones presentes en los estudios de la Argumentación, de la Lingüística de la Enunciación y del Análisis del Discurso. Por otro lado, nos guiaremos por la base metodológica del Paradigma Indiciario. Como hipótesis, abogamos que la estructura ético-patémica establece un vínculo identitario y empático entre los interlocutores en la construcción de los discursos polémicos, caracterizados por la dicotomización, la polarización y la descualificación de la voz del otro.

Palabras-clave: ethos; pathos; enunciación; polémica.

\section{Considerações iniciais: o estabelecimento dos vínculos discursivos na democracia}

"Isso virou uma polêmica!". Quantas vezes já ouvimos ou lemos esse enunciado na atualidade? A sua recorrência é sintoma de um fenômeno cada vez mais explícito em nossa sociedade: a resistência ao mundo líquido da teoria baumaniana, em que os vínculos são fluidos, escorregadios, transbordantes, o que incentiva "o desengajamento e a arte da fuga" (BAUMAN, 2001, p. 22).

Sobre essa afirmação, o psicanalista Pedro Santi (2019) nos destaca que existem duas formas de resistência a esse mundo líquido. A primeira se refere à estruturação de coletivos (feminino, LGBT, vegano, negro, entre outros grupos) que legitimam a essência de um ser, construindo uma espécie de amparo, de relevância e de identidade entre os integrantes de um grupo. Basicamente, esses agrupamentos empoderam o indivíduo ao acolher, legitimar e oferecer um sentido à sua experiência e ao seu discurso. Já a segunda, representada pelo "novo conservadorismo", se identifica por resgatar o sentimento da "raiz perdida", em que se reivindica o retorno de regras claras, de valores conservadores e de concepções tradicionais de família e de religião.

Desse modo, para alicerçar as bases dessas resistências do individual em uma coletividade que, por sua vez, forma grupos polarizados, é necessária a existência de vínculos, tecidos pelos fios da identificação e da empatia entre os indivíduos. Embora esteja presente essa tessitura no nosso cotidiano, tal fenômeno é complexo para 
ser identificado e apreendido devido aos inúmeros elementos que participam dessa elaboração.

A dinâmica de resistência a partir dos coletivos se dá em um cenário democrático, em que se pretende a coexistência, não sempre pacífica, da liberdade e da igualdade. Como nos destaca Charaudeau (2016), a democracia permite que se articule uma opinião pública como voz popular que influencia um processo de delegação de poder do povo a uma instância soberana. Retomando as palavras do intelectual Marcel Gauchet, Charaudeau (2016, p. 158) esquematiza a noção de democracia a partir de três eixos:

(i) a democracia se fundamenta num direito, o direito que legitima o poder como vindo de baixo, da vontade do povo; (ii) o poder se exerce num cenário político, que, ao mesmo tempo, estabelece limites ao exercício do poder e se institui como garantidor do vínculo de coexistência dos indivíduos, fundando o Estado-nação; (iii) assim sendo, o poder na democracia se caracteriza por sua autonomia, sua faculdade de gerir os interesses da sociedade, tendo que prestar contas apenas a esta. A democracia, portanto, nunca está completa, ela se faz a cada momento e se transforma com o tempo.

Ao considerar tal noção, o analista francês destaca duas contradições. Por uma parte, a aspiração à liberdade do indivíduo versus a aspiração ao controle racional dos interesses sociais. Por outra parte, o atendimento aos interesses particulares do indivíduo versus o atendimento aos interesses gerais da coletividade. Portanto, para alcançar um equilíbrio entre essas dinâmicas contraditórias, se torna essencial a relação entre o poder e o contrapoder, esse último representado pela voz crítica e reivindicativa:

O contrapoder é também, e talvez principalmente, o que vem da instância cidadã. Esse é o lugar da opinião, que discute e é mandatária de representantes segundo o princípio da confiança. Tem, pois, um poder de decisão temporário e um direito de olhar permanente sobre a ação das pessoas de que é mandatária. Esse contrapoder passa, principalmente, pela emergência de uma opinião (coletiva), depois, eventualmente, por uma forma de ação de reivindicação. (CHARAUDEAU, 2016, p. 158).

Entre os vários lugares simbólicos em que a opinião pública se manifesta, os gêneros localizados na seção de opinião dos jornais se mostram como um lugar privilegiado para a articulação dessas vozes. Ao aproximarmo-nos desse universo, percebemos que a seção das colunas e dos blogs possui uma característica específica: a especificação de um nome que constrói um estilo e uma imagem de si não somente com o objetivo de fidelizar leitores, mas também de ter prestígio como representante de uma opinião pública reconhecida e legitimada pelo número de acessos e comentários que suscita. Tal plano só é possível graças ao estabelecimento de vínculos por meio da aproximação de figuras discursivas, instigando o surgimento de efeitos patêmicos. 
Com a meta de iluminar o processo de entrelaçamento dos vínculos, a partir da perspectiva enunciativo-discursiva, pensamos em abordar tal problemática por meio de publicações jornalísticas, cuja relação entre escritor e leitores se estrutura explicitamente pela criação de um determinado ethos que vise à identificação com determinado perfil de leitores. Tal estrutura tem como alicerce certos efeitos patêmicos. Entre as várias opções oferecidas no domínio discursivo jornalístico brasileiro, escolhemos os textos dominicais do colunista da Folha de S. Paulo, Antonio Prata (2018-2019). Nossa eleição se baseia na mescla entre quatro fatores: a explicitação de uma consciência metadiscursiva, o emprego recorrente da ironia, a ênfase na oralização da modalidade escrita e a combinação equilibrada entre uma visão intelectualizada e uma prosaica dos fatos, muitas vezes explicados metaforicamente.

Para alcançar essa finalidade, teremos o auxílio de um enquadre teórico do âmbito da Linguística da Enunciação, da Análise do Discurso e dos Estudos da Argumentação, além da Linguística Textual, uma vez que a natureza do corpus requer uma abordagem interdisciplinar. Já como enquadre metodológico, o nosso olhar será guiado pelo paradigma indiciário. Além disso, para nortear a nossa linha de raciocínio, podemos esboçar hipóteses a partir de algumas considerações guiadas por noções psicanalíticas e sociológicas sobre a psicologia das massas. Após desenhar o alicerce analítico de nosso percurso, convém seguir para a próxima etapa.

\section{Enquadre teórico-metodológico: como o sujeito pragmático se transforma em sujeito discursivo que faz emergir efeitos patêmicos?}

Diante dos questionamentos que o nosso corpus jornalístico nos provocou, a primeira providência seria buscar no universo teórico que estuda os fenômenos linguísticos, campos que permitissem entender melhor as articulações entre sujeito e língua(gem). Entre as possibilidades que se apresentaram, as primeiras discussões se deram na área da Linguística da Enunciação, área que reúne uma série de teorias que discutem os fenômenos enunciativos, a partir da problematização da dicotomia língua e fala, com o objetivo de explorar a questão da (inter)subjetividade na linguagem, conforme as ideias de Flores e Teixeira (2005).

Ao discutir a (inter)subjetividade na linguagem, um dos temas recorrentes é como forma e sentido se articulam na enunciação do sujeito. Ao textualizar o seu discurso, o sujeito pragmático vai deixando suas marcas estilísticas na materialidade, o que vai constituir os indícios de subjetividade. No decorrer desse processo, o sujeito pragmático dá lugar a um sujeito discursivo que se constitui por uma imagem que escapa ao projeto consciente da figura do escritor / falante.

Discini (2015) destaca a importância de apreender o sujeito ao longo do processo de construção textual, ou seja, compreender os modos de aspectualização do sujeito. Tal 
aspectualização se sistematiza por meio da descrição dos mecanismos linguísticos que possuem formas específicas de:

a) relacionar-se com o tempo-espaço dos acontecimentos, regidos pelo andamento e pela tonicidade da percepção;

b) conotar o léxico de determinada totalidade, de modo a apresentar o estilo como um todo que transcende suas partes. (DISCINI, 2015, p. 165).

É importante mencionar que esses movimentos linguístico-discursivos se dão na materialidade do enunciado que é o produto da enunciação, localizando a coordenada triádica de pessoa, tempo, espaço. Já a enunciação é o "colocar em funcionamento a língua por um ato individual de enunciação" (BENVENISTE, 2006 [1965], p. 82). Desse modo, necessitamos observar a materialidade aqui presente sob uma perspectiva enunciativa, uma vez que o homem se constitui na e pela linguagem como sujeito, noção já presente nos preceitos benvenistianos (BENVENISTE, 1995 [1966], p. 286). No entanto, as marcas não estão presentes na enunciação, muito menos no sujeito pragmático, mas sim na materialidade do enunciado, na qual emerge o sujeito discursivo que articula um ethos.

Com relação a esse termo, ele faz parte da tríade aristotélica ethos, pathos e logos, vinculados, respectivamente, às noções de locutor, de interlocutor e de discurso. Tal tríade foi replicada, com diferentes terminologias, na maioria dos estudos argumentativos, pragmáticos e textuais. Com isso, comprovamos a relevância dessas noções durante o percurso histórico dos estudos linguísticos, das quais enfatizaremos os dois primeiros termos nesse trabalho.

Em primeiro lugar, destacaremos a noção de ethos. Essa noção aristotélica nasce atrelada à ideia de credibilidade do sujeito pragmático como argumento em um discurso de natureza argumentativa. Nos estudos discursivos atuais, temos entendido o ethos como "uma noção discursiva", que se elabora a partir "do discurso e não de uma imagem do locutor exterior a sua fala", ancorado em um "processo interativo de influência do outro", que se vincula a uma perspectiva sócio-discursiva (MAINGUENEAU, 2008, p. 17). Como consequência, essa noção se ajusta a uma visão enunciativa, posto que o locutor mobiliza a língua em uma cena de enunciação. Ao pensar em nosso corpus, mais do que discutir sobre as ações do sujeito articulista do jornal, questionamos os fenômenos imbricados na imagem tracejada na materialidade linguística e, com base nisso, esboçaremos nossas hipóteses a partir de um olhar interdisciplinar.

Atrelada ao ethos, temos a concepção de fiador por parte da visão do interlocutor: um esboço de um "corpo enunciante historicamente especificado", que apresenta uma 
espécie de "caráter" e de "corporalidade", de naturezas estereotipadas (MAINGUENEAU, 2008, p. 17). Essa ideia se torna básica se pensarmos que o locutor, no papel de articulista, se conecta diretamente ao sujeito enunciante e a um ethos, ainda mais porque existe uma assinatura que nomeia esse sujeito escritor que possui sua imagem discursiva na materialidade textual.

Ainda tratando sobre o ethos, com base nas palavras do pesquisador francês, temos um continuum cujas extremidades estão, em um lado, no ethos dito (aquele em que o sujeito evoca sua própria enunciação) e, em outro, no ethos mostrado (aquele em que o sujeito se mostra por meio dos indícios na materialidade linguística). Também nessa visão esquemática, percebemos que existe uma combinação dinâmica entre o ethos dito e mostrado em nosso corpus, já que a necessidade de vinculação entre interlocutores implica oferecer um simulacro de um dizer sobre si mesmo reportado a um fiador.

Em segundo lugar na referência da tríade aristotélica, inicialmente, o pathos se refere ao argumento baseado na indução de um estado emocional do interlocutor. Plantin (2006, p. 371) sistematiza o conceito como um "transbordamento emocional, geralmente, sem sinceridade", permitindo a incitação de uma "emoção no interlocutor ou no auditório pela ação discursiva". Lembramos que tal "emoção" é entendida como um "simulacro de emoção", uma vez que está a serviço de fins estratégicos na construção de um cenário de patemização.

Charaudeau (2010) ressalta que há um caráter social da emoção de natureza discursiva, visto que ela legitima um sentimento de pertencimento a um grupo ao articular uma consciência coletiva. Tudo isso envolve uma questão de crenças, de saberes, de representações psicossociais e de intenções em prol de um engajamento ou posicionamento desejável por parte do interlocutor, embora não sempre alcançado. Apesar da área linguística não ter instrumental para trabalhar com as emoções propriamente ditas, podemos nos aproximar de seus efeitos no âmbito linguístico nas relações de coconstrução discursiva por meio do que chamaremos de efeitos patêmicos, considerando que sempre são pensados virtualmente, pois podemos comentar sobre os efeitos pretendidos, mas nunca sobre os efeitos produzidos de fato.

Ao refletir sobre os efeitos éticos (relativo ao ethos) e patêmicos pretendidos, notamos que, além da questão da construção de uma opinião pública, temos o papel da polêmica na argumentação em tempos de crise do regime democrático. Ao recuperar as palavras de Kerbrat-Orecchioni sobre imagens, Amossy (2005) enfatiza a dinâmica dos "jogos imagéticos", em que a materialidade linguística pode dar sinais sobre quais imagens um locutor faz de si mesmo, de seu(s) interlocutor(es) e de como seus interlocutores the imaginam. Esse jogo auxilia na criação de um vínculo empático, considerando o termo "empatia" como um efeito de sentido de identificação que, no âmbito discursivo, significa colocar-se no lugar do outro. Em tal perspectiva, não vinculamos o termo a uma visão 
psicologizante, mas a uma perspectiva patêmica com a intenção de fortalecimento coletivo e reconhecimento de uma voz de representação.

Para discutir esse tema, nos basearemos no estudo monográfico de Amossy (2017) em que se discute a pertinência da polêmica na argumentação que auxilia na elaboração de um espaço público e de uma deliberação cidadã. A visão da retórica tradicional concebe a argumentação como um procedimento que objetiva a negociação de diferenças que permita chegar a um consenso entre as várias posições divergentes. No entanto, nos espaços democráticos, nem sempre temos o consenso, mas sim o dissenso, o que é mais realista, posto que, diante do pluralismo social, o conflito se torna indispensável para evolução social, sendo inerente à política.

Reflexões sobre a cultura democrática do dissenso deveriam logicamente levar a ver na confrontação polêmica um modo de gerenciamento inevitável, e útil, dos conflitos. Se, de fato, o conflito é inevitável em nossas democracias pluralistas e se o cerne da democracia não é o consenso, mas gestão do dissenso, então a polêmica como confronto verbal de opiniões contraditórias que não leva a um acordo utópico deve ser reconsiderada em profundidade. É, por conseguinte, uma retórica do dissenso que é necessário desenvolver, na qual a polêmica deve ter lugar de destaque. (AMOSSY, 2017, p. 37-38, grifo da autora).

Ao considerar que a maioria dos gêneros do domínio jornalístico possui traços polêmicos, é conveniente definir o fenômeno e suas características. Ao esquematizar os estudos de Amossy (2017, p. 49), podemos definir que a polêmica é "um debate em torno de uma questão de atualidade, de interesse público, que comporta os anseios das sociedades mais ou menos importantes numa determinada cultura". Como características principais, em um âmbito conflitual, temos: a) a dicotomização (posições antagônicas e excludentes que não possuiriam solução); b) a polarização (formação de grupos antagônicos representados por atores, em que os actantes se reuniriam em torno de valores e de solidariedade) e c) a desqualificação da voz do outro (difamação e deslegitimação do ethos do outro por acreditar na existência de má fé e má intenção).

Diante desse quadro, vemos que o ethos se constrói duplamente em direção a dois grupos de interlocutores: por um lado, buscando a identificação empática e, ao mesmo tempo, delineando uma aliança por meio do esboço de um "inimigo em comum e demoníaco". Quanto à questão patêmica, observamos que o efeito passional discursivo, para criar um movimento de indignação, visa ao engajamento emocional dos interlocutores, algumas vezes com violência e virulência verbais. Em muitos casos, e graças às mídias, notamos uma espetacularização oferecida a um público.

Tendo em vista que o nosso corpus está formado por publicações do gênero coluna (artigos assinados e com publicação regular em jornais e revistas, que tratam de assuntos do cotidiano ou de interesse social, a partir de uma perspectiva pessoal e crítica do 
locutor), observamos que este gênero pode ser atravessado por um continuum desenhado por Amossy (2017) para recolocar o discurso polêmico no âmbito da argumentação e, consequentemente, na área da deliberação democrática.

\begin{abstract}
Se aceitarmos considerar a argumentação um contínuo no qual o grau de confrontação explicita respostas divergentes, relativas a uma mesma questão que varia em intensidade, a polêmica se situa, manifestamente, numa de suas extremidades. No centro, encontra-se a argumentação como troca regrada de teses antagônicas; em um dos polos, o discurso visando à persuasão que não ataca diretamente a posição contrária, e até que nem apresenta a posição do outro e finge não ter nenhuma visada de influência; e no outro polo, o choque de teses antagônicas que dizem respeito à polêmica. Nesse sentido, a polêmica não é um gênero do discurso (ela atravessa os tipos e os gêneros de discurso), mas uma modalidade argumentativa, entre outras. (AMOSSY, 2017, p. 67).
\end{abstract}

Como pretendemos discutir, vemos que uma parte dos gêneros do domínio jornalístico possui a natureza polêmica, variando em direção à argumentação persuasiva, conforme a imagem do auditório e o objetivo de que determinado locutor se transforme em uma voz representativa de um coletivo. Nesse caso, os traços da polêmica podem transformar-se, justamente, em um vínculo empático entre interlocutores.

Após termos a nossa fundamentação teórica esquadrinhada, ainda é necessário apresentar nosso enquadre metodológico. Ao ter ciência de que nem todas as teorias enunciativas possuem uma metodologia fixa, em especial a benvenistiana, decidimos assumir uma perspectiva de transversalidade enunciativa, em que o olhar analítico atravessa os vários mecanismos que se articulam na tessitura do texto. A isso acrescentamos uma postura metodológica guiada pelo Paradigma Indiciário (GINZBURG, 1989) que enfatiza a importância de notar os indícios que, em um primeiro momento, são irrelevantes e secundários, mas que, no decorrer da análise, são primordiais para construir um conjunto complexo.

Com relação ao corpus, este está composto por 39 textos publicados dominicalmente na coluna do escritor e roteirista Antonio Prata, no jornal Folha de S. Paulo, entre os meses de setembro de 2018 e maio de 2019 (período pré e pós eleitoral para presidência da república brasileira). Cabe alertar que Prata é um dos articulistas que se destaca pelo seu humor ácido e constantes ironias como mecanismo estilístico. E, embora suas publicações estejam em uma coluna, ele se reconhece como cronista, devido aos recorrentes comentários críticos e polêmicos, relacionados a temas políticos, culturais, econômicos e cotidianos, típicos das crônicas.

Após indicarmos nosso percurso teórico-metodológico, nos dirigiremos à próxima etapa do trabalho, a qual se refere aos comentários analíticos e às hipóteses de interpretação 
diante dos fenômenos enunciativos e discursivos encontrados durante as análises textuais. Dados as características e o recorte desse trabalho, organizaremos nosso trajeto por meio dos principais mecanismos linguísticos de emprego recorrente, alguns deles já parcialmente abordados em uma anterior análise (FERNANDES, 2016).

\section{Comentários analíticos: em busca de uma identificação na formação de vínculos}

Para iniciar esta fase do trabalho, é importante recordar as características das crônicas. De acordo com Costa (2008), a crônica se configura como um texto breve e de interlocução direta com o leitor, que pretende refletir, com argúcia, sobre temas cotidianos, políticos, culturais, sociais, entre outros. Nesse caso, podemos dizer que existe uma espécie de intergenericidade, quando um gênero teria a função de outro, embora não seja completa. Mais especificamente: temos textos com características primordiais de uma crônica, mas com um formato de coluna. É importante atentar para essas peculiaridades porque a própria combinação dos dois gêneros aqui citados pode indicar o movimento de aproximação com o interlocutor: a regularidade da publicação com uma assinatura que conduz o interlocutor em direção à figura de um fiador e à crítica sagaz em um tom espontâneo.

Muito mais do que o tema ou os argumentos para defender uma perspectiva no logos, temos o modo de dizer que pretende criar um modo de ser discursivo para aproximarse do outro. Nesse sentido, o ethos ganha os contornos tradicionais ao transformar-se em um argumento por meio da credibilidade de quem enuncia. O peculiar é que esse "alguém" é uma figura discursiva, um personagem estruturado para "cativar" o interlocutor. Posteriormente, essa figura discursiva sedutora pode servir como gerenciador "parcial" de um conflito que é o cerne da polêmica. Como indica Amossy (2017, p. 53), a polêmica possui uma violência conflitual, posto que é "uma manifestação discursiva sob forma de embate, de afrontamento brutal, de opiniões contraditórias que circulam no espaço público". Nesse caso, essa crônica-coluna surge como a materialização da voz de um representante que desvela o conflito discursivo violento de modo a desqualificar o discurso oponente, esboçar um grupo e estabelecer uma dicotomia de opiniões.

Nesse momento, cabe recordar algumas pesquisas de natureza sociológica que tratam sobre o perfil do brasileiro. Podemos entender o brasileiro como um indivíduo que tem uma capacidade relacional, "do antigo com o moderno, que tipifica e singulariza a sociedade brasileira" (DaMATTA, 1986, p. 20). Já Almeida (2007, p. 26) atesta que, mesmo havendo a influência do nível de escolaridade, parte da mentalidade brasileira se distingue por determinados atributos que possibilitam dizer que o brasileiro tende a: a) ser hierárquico; b) ser patrimonialista, c) ser fatalista e "familista"; d) apoiar o "jeitinho brasileiro"; e) não confiar nos amigos; f) não ter espírito público; g) defender a "lei do Talião"; h) ser contra o liberalismo sexual; i) ser a favor da intervenção do Estado na economia e j) ser a favor da censura. 
Entre as peculiaridades anteriores, destacamos o familismo, ou seja, a confiança nos integrantes da família. De acordo com a pesquisa de Almeida (2007, p. 115), 84\% dos brasileiros confiam na família; $30 \%$ nos amigos; $30 \%$ nos colegas de trabalho; $23 \%$ nos vizinhos e $15 \%$ na maioria das pessoas. Esses dados evidenciam que, possivelmente, construir uma imagem de proximidade e familiaridade é importante para estabelecer uma trajetória exitosa durante o processo argumentativo, ainda mais em um momento social em que existe uma tensão entre grupos, na sociedade brasileira, em torno do exercício da democracia, da liberdade de expressão e dos direitos sociais. No presente caso, é basilar que o locutor se construa mediante a um papel de defensor ou opositor de uma proposta, instaurando, segundo nomeia Amossy (2017, p. 56), uma operação de "polarização", que consiste em um "reagrupamento em campos adversos entre os participantes", sendo de ordem "social", em que há uma oposição entre "nós versus eles". Desse modo, a figura discursiva do locutor pode concentrar, a seu redor, um grupo, cujos membros partilham uma solidariedade e um conjunto de valores que o locutor coloca como fundamentais.

É importante ressaltar que, ideologicamente, o corpus apresenta ideias que antagonizam com a tendência do familismo. Porém, ainda assim, o locutor discursivamente cria uma imagem de proximidade a um grupo oposto a tal tendência, o que nos traz um indício que, independente da disposição ideológica, a questão do vínculo de proximidade é capital para a argumentação, que já apresenta traços da polêmica, em primeiro lugar, por meio da polarização representada nos textos do corpus.

Após a discussão sobre gênero textual, presente no campo da Linguística Textual, é coerente pensarmos na tipologia textual. Nesse quesito, podemos notar que se apresenta, nessa ordem, a maior ocorrência da 1) tipologia narrativa, 2) tipologia dialógica e 3) tipologia argumentativa. Percebemos que, mesmo em sequências argumentativas, existe a tendência de relatar fatos supostamente vivenciados pelo fiador. Isso pressupõe que se crie o efeito de uma relação de implicação entre interlocutores, uma vez que, ao acompanhar o relato, o interlocutor tende a engajar-se emocionalmente ao colocar-se no lugar do outro de maneira mais sutil e direta. Podemos perceber tal efeito na amostra a seguir:

(01) Esta noite eu tive um sonho bem louco. Na verdade, começou como um pesadelo. O Brasil ia eleger um presidente fascista que falava em torturar e matar oponentes, em acabar com todos os ativismos, em vender as reservas indígenas, em militarizar as escolas, em submeter o Ministério do Meio Ambiente ao da Agricultura, em proibir a palavra "gênero" dentro das salas de aula e outras bizarrices que não faziam sentido e eu não lembro direito.

Eu tentava avisar as pessoas "Olha o que ele tá falando! Olha que absurdo!", mas ninguém ouvia, quer dizer, as pessoas ouviam, mas diziam que iriam votar no candidato fascista porque qualquer coisa era melhor que o PT. 
Eu insistia "Gente, o PT fez besteiras, mas o Haddad não é a Dilma e mesmo o pior Armagedom dilmístico é melhor do que o que esse cara prega!". Aí as pessoas diziam que o que o candidato fascista falava não era verdade, ele só estava brincando de fingir que era fascista a vida inteira, mas quando fosse eleito ele iria parar com a brincadeira. (PRATA, A. Um sonho, 14/10/2018. Disponível em: https://www1.folha.uol.com.br/colunas/antonioprata/).

Nesse fragmento, o locutor emprega as sequências narrativas e dialógicas para defender sua tese e contra-argumentar as refutações explícitas no texto. Ao invés de escolher um formato clássico da sequência argumentativa, se subverteu o formato, dando uma "roupagem" típica das sequências narrativas e dialógicas. E qual seria o objetivo? Como nos fenômenos linguísticos nada é fruto do acaso, nossa hipótese é a de que a articulação das formas dessas duas tipologias (narrativa e dialógica) com o objetivo de uma terceira (tipologia argumentativa) se deve pelo surgimento de um efeito patêmico de familiaridade e implicação, esboçando uma cenografia enunciativa de conversa espontânea e cotidiana embutida no processo onírico. Além disso, como discute Amossy (2017, p. 55), verificamos a presença do fenômeno de reapropriação do discurso do outro, de forma que haja uma integração desse discurso a um sistema próprio do discurso do locutor, por meio da inversão. Nesse exemplo, citar o discurso do outro é uma forma de negação, a fim de caracterizá-lo como modelo de incoerência e ultraconservadorismo. Por outro lado, também se apresenta a desqualificação do outro e do seu discurso, com a construção da imagem de um grupo como "símbolo do erro e do mal", não só pela desqualificação do discurso como do indivíduo mesmo (AMOSSY, 2017, p. 58).

Ao dirigirmos um olhar pormenorizado aos mecanismos de textualidade referentes à coesão eà coerência, observamos que se destacam simulacros de enunciados de estrutura oral; paralelismos sintáticos caracterizados pela gradação; diversidade de registros a partir de léxico especializado, jargões e neologismos, dinamizando um movimento do formal ao informal e vice-versa. Além disso, temos a recorrência de perguntas retóricas que insinuam a presença e o papel do leitor na coconstrução enunciativa, assim como de enunciados exclamativos recorrentes. Além do fragmento anterior, apresentamos o próximo como exemplo dessas características:

(02) Uma amiga me liga, arfante. Acabou de ser assaltada no táxi. Arma na cabeça, coisa e tal. Quando se acalma um pouco vem um estranho sentimento de gratidão, afinal podia ter sido pior, está viva, não se feriu, que sorte a filha de 11 meses não estar junto. Depois faz-se um silêncio que é pura desolação. "Que que a gente faz?", me pergunta.

Ela não se refere ao assalto, a como diminuir os índices de violência na cidade de São Paulo. A pergunta é mais ampla, a mesma que nos fazemos há alguns anos quando cai um prédio, uma vereadora é assassinada, um museu pega fogo, uma bala perdida mata uma criança, uma policial de 27 anos, de folga, é assassinada pelo PCC [...]. 
No começo do ano, passei com a minha filha pelo estádio do Pacaembu, onde uma enorme fila de torcedores sem camisa aguardava a abertura das bilheterias. "Eles são índios, papai?". Meu radar politicamente correto imediatamente ligou o alerta laranja: "Não, eles não são índios, eles são pessoas da cidade como eu e você". "Mas eles são marrons e não usam camisa. Eles são índios". Então abaixei um pouco a guarda e constatei que de fato nós éramos brancos e eles eram pretos e pardos e provavelmente havia naquela fila mais DNA indígena do que dentro do nosso carro. Senti um gosto amargo: minha filha estava tendo uma das primeiras aulas práticas de segregação racial e social.

Se eu quisesse mandar um sincerão, diria "Veja, a base da população é composta por pretos e pardos e a ponta por brancos, porque os brancos vieram pra cá e escravizaram os índios e trouxeram milhões de escravos negros e mesmo depois de quase 150 anos da abolição nós temos conseguido, com rigor e aplicação, manter inalterada a pirâmide". (PRATA, A. Que que a gente faz?, 30/09/2018. Disponível em: https://www1.folha.uol.com.br/colunas/antonioprata/).

Além das relações tipológicas anteriormente comentadas, temos aqui a estrutura da oralidade com sintaxe concatenada e indicação de reduções fonéticas, combinando estilo direto, indireto e indireto livre. As vozes enunciativas se entrecruzam, mas sempre orquestradas pela "batuta" do locutor que rege essa sinfonia textual em que três cenas enunciativas se entrecruzam: o relato sobre o assalto da amiga, a reflexão sobre o questionamento da colega que é uma pergunta retórica encoberta para o leitor e o diálogo entre locutor e seus filhos dentro do carro. Cada cena está caracterizada pelos seus personagens e peculiaridades da "cenografia", conjunto este que permite a diversidade do léxico que indica distintos registros e áreas (a título de exemplo de pólos léxicos opostos: DNA e sincerão). Também destacamos as sequências de tipologia explicativa em registro formal.

A articulação coesiva que garante a coerência entre três cenas distintas permite esboçar um ethos polifacético, que se vincula a vários interlocutores por meio do simulacro de vivências comuns, diálogos familiares e reflexões que sugerem indignação diante da realidade social, mas sempre combinam o perfil do fiador entre o sujeito, por um lado, culto, enciclopédico e instruído e, por outro, "gente como a gente". Eis aqui a capacidade relacional de unir os opostos como singularidade brasileira, aspecto já destacado por DaMatta (1986). Portanto, para vincular-se ao interlocutor brasileiro, o ethos que emerge da materialidade deve movimentar-se entre cenários multifacetados, tendo a ambiguidade como aliada para incitar o efeito patêmico de empatia.

Por outro lado, o locutor também surge como voz que nomeia e caracteriza os grupos sociais que se configuram como o jogo de polarização do conjunto binário "nós" versus "eles", em que as desigualdades estruturais brasileiras aparecem. Diante disso, o locutor se alça como a voz que enuncia a pergunta de todos os membros do grupo ao qual representa: "Que que a gente faz?". O esboço de resposta nos conduzirá à dicotomização, em que se exacerbam "as oposições até torná-las inconciliáveis" (AMOSSY, 2017, p. 56). 
Nesse momento analítico, vamos dirigir nosso olhar às nuances retóricas no conjunto de nosso corpus. Entreosvários tipos deargumentos apresentados, notamos que se destacam aqueles fundados no princípio da não contradição, pertencentes aos argumentos quase lógicos tão estudados no Tratado da Argumentação, de 1958. Como didatiza Fiorin (2015, p. 116), "os argumentos quase lógicos são os que lembram a estrutura de um raciocínio lógico, mas suas conclusões não são logicamente necessárias", sendo argumentos que se valem do que é "possível, plausível, provável", mas não lógicos obrigatoriamente. Por sua vez, dentre as várias subcategorias de tal classe, os argumentos fundados no princípio da não contradição se referem à (não) incompatibilidade de argumentos.

Como subcategorias, temos o argumento de retorção, em que se contrapõem ideias, evidenciando a incompatibilidade de uma hipótese por meio da manobra em que o "argumento volta-se contra aquele que enunciou" (FIORIN, 2015, p. 142). Também faz parte dos argumentos fundados na não contradição o argumento de redução ao absurdo que "consiste em tomar uma proposição como verdade, para dela tirar conclusões absurdas" (FIORIN, 2015, p. 143). Como exemplo desse último, apresentamos o próximo fragmento:

(03) Eu queria muito ter que responder perguntas simples do tipo "Como os bebês são feitos?", mas no Brasil o tabu é mais embaixo. "Por que ela dorme na rua?". "Por que ela é pobre?". "Por que ela não tem trabalho?". "Por que ela não foi pra escola?". "Por que a mãe dela também não foi pra escola?". "Por que a avó dela também não foi pra escola?". "Por que as pessoas pobres são sempre marrons?". O que balbucio à guisa de resposta tem a eficácia de um saquinho de Floc Gel sobre a lama da Vale: "Elas não são marrons, elas são negras".

Pra que me agachar no chão durante a festa e explicar pacientemente ao meu filho que ele tem que emprestar o Batman pro Guilherme "porque se todo mundo emprestar os brinquedos pra todo mundo, todo mundo vai poder brincar com todos os brinquedos"? Se eu fosse sincero e educasse pra realidade brasileira e não pros meus delírios utópicos ultrapassados eu deveria dizer 1) "Não empresta, você é maior do que o Guilherme, empurra o Guilherme, pisa no Guilherme, cospe no Guilherme e mostra quem manda" ou 2) "Empresta, o Guilherme é maior do que você, se você não emprestar o Guilherme vai te empurrar, vai pisar em você, cuspir em você e mostrar quem manda".

A dissonância entre a realidade brasileira e o que meu filho aprende em casa e na escola é da ordem da psicose. Dois mais dois são quatro, nós insistimos em dizer, mas sabemos que se você tiver os contatos certos, dois mais dois são cinco ou quinhentos, assim como também pode ser zero ou menos mil se você tiver nascido no lugar errado, com a cor errada, o gênero errado, a orientação sexual errada. (PRATA, A. A educação pelas trevas, 17/02/2019. Disponível em https://www1.folha.uol.com.br/colunas/antonioprata/).

A hipótese elaborada, na cena de enunciação, para que o pai explicasse ao filho o motivo pelo qual ele deve ou não emprestar o brinquedo ao amigo é um exemplo do argumento 
de redução ao absurdo, já que o locutor leva a justificativa para o campo do antiético e imoral. No entanto, com o objetivo de mostrar a lógica brasileira pautada no mandonismo e na hierarquia, oposta aos princípios igualitários e democráticos (caracterizados sarcasticamente como delírios utópicos ultrapassados), o locutor inicia o argumento por meio de uma condicional que explicita a realidade brasileira: Se eu fosse sincero e educasse pra realidade brasileira e não pros meus delírios utópicos ultrapassados eu deveria dizer [...].

Convém salientar o emprego massivo da técnica argumentativa da ironia, entendida aqui a partir de uma perspectiva enunciativa em que existe "a ambigüidade do enunciado, a duplicidade da enunciação" (BRAIT, 2008, p. 107). Em outras palavras, em um mesmo enunciado há mais de uma voz queé representada pelas enunciações que o locutor articula, valorizando ou refutando, conforme os vários mecanismos linguísticos sistematizados ou segundo a cena de enunciação. No caso do sintagma delírios utópicos ultrapassados, temos um enunciado que representa duas enunciações: a) voz que representa aquele que acredita piamente que a postura é um desatino incongruente com a realidade brasileira e b) voz que representa aquele que é contrário à ideia de que a postura é um disparate. Habilmente, o locutor constrói o enunciado em um entorno linguístico, intertextual e discursivo que indica a sua posição diante das enunciações. O resultado disso tudo é a deslegitimação do discurso do outro (que no caso representa o discurso da meritocracia e do neoliberalismo), transformando-o em oponente, uma vez que:

Nessa relação com o outro, todo um leque de abordagens antagônicas se abre. o procedimento mais atenuado consiste em atacar a palavra do outro, tendo ele como alvo apenas por meio dela. O Oponente refuta, assim, as razões do adversário, mostrando que seu discurso é indigno de confiança e não merece que o apoie. A polêmica responde, então, ao discurso adverso, enfraquecendothe os argumentos por todos os meios possíveis, seja pela negação, seja pela reformulação orientada, seja pela ironia, seja pela modificação de propósitos... (AMOSSY, 2017, p. 59).

Ainda nesse aspecto, é importante mencionar o emprego frequente de estruturas enunciativo-discursivas da heterogeneidade mostrada para aludir o outro nos enunciados desse outro e nos do locutor para reforçar a oposição "nós" versus "eles". Vemos uma série de mecanismos de heterogeneidade mostrada marcada (discurso direto, discurso indireto, aspas, glosa, jogo de palavras) e não marcada (ironia, alusão, discurso direto livre, pastiche, metáfora, imitação, jogo de palavras). Do ponto de vista da Análise do Discurso e da Psicanálise, Authier Revuz (2004) defende a importância de olhar a enunciação em sua característica plural de vozes por meio da heterogeneidade constitutiva e da heterogeneidade mostrada. Sobre essa última modalidade, na qual temos interesse, a professora emérita de Linguística na Universidade Paris III argumenta que: 
As marcas explícitas de heterogeneidade respondem à ameaça que representa, para o desejo de domínio do sujeito falante, o fato de que ele não pode escapar ao domínio de uma fala que, fundamentalmente, é heterogênea. Através dessas marcas, designando o outro localizadamente, o sujeito empenha-se em fortalecer o estatuto do um. É nesse sentido que a heterogeneidade mostrada pode ser considerada como um modo de denegação no discurso da heterogeneidade constitutiva que depende do outro no um. (AUTHIER-REVUZ, 2004, p. 73-74).

A partir dessa perspectiva, acreditamos que, ao explicitar o outro no interior da tessitura do enunciado do locutor, faz emergir um ethos com efeito matizado pela voz e pela perspectiva do outro, seja pela identificação, seja pela diferenciação. Dessa maneira, esse ethos nasce das "entranhas" da voz de um outro e, portanto, pode-se estabelecer vínculos legitimados pelas palavras de um coletivo. Mas, é evidente, sem perder a ilusão imagética de ser um sujeito e fiador autônomo e crível. No entanto, é importante ressaltar que o efeito discursivo é desqualificar a tese e a figura do oponente para que o locutor possa alçar-se como representante de um grupo específico, que se exclui de um outro, que é ridicularizado e demonizado, em especial, pelos recursos da heterogeneidade marcada e não marcada.

Como alertamos em um estudo anterior (FERNANDES, 2016), a ironia pode ser um fenômeno contraproducente se não levarmos em conta as peculiaridades dos conhecimentos compartilhados, os vínculos patêmicos de empatia e os processos de identificação. Ainda assim, notamos que é um recurso retórico cada vez mais utilizado, pois permite operar teatralmente a cena "rimos com você, interlocutor, do outro, o inimigo comum", ajustando-se ao esquema de polarização e desqualificação do outro, deslegitimando a voz do diferente. Em suma, o movimento principal é mostrar a falta de lógica, assim como no argumento de retorção da amostra a seguir:

(04) Meu amigo Gustavo me mostrou outro dia o anúncio de um apartamento à venda com a seguinte frase: "Grande potencial para reforma!". Maneira não muito sutil que a imobiliária arrumou para informar que o imóvel estava caindo aos pedaços. "O Brasil é o país do futuro" não deixa de ter o mesmo significado: se é no futuro que nos realizaremos é porque no presente, bem, tá cheio de taco solto, fiação podre, infiltrações e trincas. No entanto, postergando as reformas, aqui vivemos. É muito esquisito ser brasileiro.

A poeta americana Elizabeth Bishop, que morou no Brasil nas décadas de 50 e 60 afirmou, sobre a cidade que talvez melhor encarne as virtudes e vicissitudes nacionais: "O Rio não é uma cidade maravilhosa; é apenas um cenário maravilhoso para uma cidade". Grande potencial para reforma! Sob nosso formoso céu, risonho e límpido, há chacinas e tráfico de drogas, desvio de dinheiro e gente morrendo nos hospitais por falta de remédios. Ser brasileiro é padecer no paraíso. (PRATA, A. Futuro do pretérito, 03/03/2019. Disponível em: https://www1. folha.uol.com.br/colunas/antonioprata/). 
Nesse fragmento, se alude à expressão procedente da obra de Stefan Zweig, por meio da qual o Brasil começou a ser adjetivado como o "país do futuro". Contudo, ao aproximar tal slogan a um anúncio imobiliário e a um comentário sobre o Rio de Janeiro por parte da poetisa Elizabeth Bishop, percebemos que, de modo perspicaz, o locutor transforma a alusão de potencial positivo em um implícito que indica uma realidade concreta e negativa. Em poucas palavras, explicita a incongruência de um argumento por meio da ideia ou do enunciado do oponente e, com um detalhe, evidenciando um perfeito deslocamento entre o conhecimento trivial e o intelectual.

Por último, destacando um aspecto eminentemente metaenunciativo e metadiscursivo, o locutor, finalmente, explicita a natureza enunciativo-discursiva de construção do ethos e de seu papel social por meio da referência direta dos processos linguísticos e textuais da elaboração do gênero:

(05) Hoje é dia 30 de dezembro, tá todo mundo na praia ou acendendo a churrasqueira: esta crônica, portanto, não será lida por viv'alma. Salvo as viv'almas do Adams e da Bia - ele assina as belíssimas ilustrações aí em cima e ela, entre outras funções mais nobres na Folha, sauva-me dod neus erros. (Opa, parece que hoje nem a Bia leu).

Talvez a piadinha metalinguística tenha ficado meio obscura, mas tudo bem: uma das vantagens de escrever uma crônica para ninguém é que a gente pode tomar certas liberdades [...]. (PRATA, A. Crônica pra ninguém, 30/12/2018. Disponível em: https://www1.folha.uol.com. br/colunas/antonioprata/).

Nessa amostra final, se observa a configuração da cenografia, na qual se desenvolve o processo textual-discursivo da escrita da presente crônica. Nela, se localizam as coordenadas de pessoa, espaço e tempo, tanto do locutor quanto do interlocutor, considerando a proximidade do final do ano. As marcas de espontaneidade e domínio metadiscursivo na explicitação dos mecanismos linguísticos evidenciam fenômenos de heterogeneidade, mas, nesse caso, explicitam a emergência de um ethos representante da ilusão do controle do seu dizer e do dizer do outro.

Como efeito patêmico, notamos um simulacro de desnudamento do locutor diante do interlocutor, emergindo um ethos ancorado pela corporificação do fiador e, consequentemente, um efeito de espontaneidade e transparência - a propósito, efeito artificial no que se refere à realidade - no modo de dizer e de ser do locutor. Porém, não podemos nos enganar por essa calculada construção metaenunciativa: o simulacro de desnudamento das vicissitudes do processo de construção textual-discursiva nada mais é do que uma tentativa de criar um vínculo empático por meio de identificação nos modos de olhar, de atuar e de dizer. 
Após esse caminho analítico e após considerar todos os indícios textuais, retóricos, enunciativos e discursivos, podemos intuir que o ethos polifacético que se desprende da materialidade linguística pode ser esboçado como irônico-crítico e intelectualdespretensioso, devido à presença de (auto)ironia, de erudição, de espontaneidade, de racionalidade e de consciência metadiscursiva. Deve-se conceber todas essas características como um simulacro, como um efeito enunciativo-discursivo pretendido e não necessariamente alcançado. Considerando as particularidades do perfil socioeducacional dos leitores ideais e as alusões à figura enunciativa do interlocutor nos textos analisados, se nota o empenho de uma construção de vínculo empático, em que o ethos que se esboça, auxiliado pela imagem do fiador, insinua a apresentar-se como uma figura com traços identificatórios com o interlocutor e, portanto, que deve ter sua voz legitimada como representante de uma opinião pública que é um contrapoder no movimento democrático brasileiro. Esses traços identificatórios estão a serviço da polarização como uma das características da polêmica, em que o locutor se torna representante da voz de um grupo.

Nesse sentido, a assimilação da posição defendida à pessoa do debatedor significa um fenômeno identitário cuja importância não deve ser subestimada. De fato, frequentemente, a tese defendida na controvérsia está tão intimamente integrada à visão de mundo do locutor, do seu sistema de valores, de seu pertencimento ao grupo, do seu estatuto social... que ele não pode se afastar dele sem perder a identidade. (AMOSSY, 2017, p. 58).

Por outro lado, como efeito patêmico pretendido, notamos que o estilo discursivo ecoa um efeito de indignação e empatia por meio das recorrentes menções diretas e indiretas ao interlocutor, alusões a cenas cotidianas e a conhecimentos e pensamentos (alguns em tom exclamativo) compartilhados e inclusão explícita do interlocutor no processo de coenunciação. Todo esse arcabouço permite o surgimento do efeito de identificação ou, até mesmo, de projeção (psicanaliticamente compreendido quando um sujeito psicobiológico projeta suas experiências nos demais indivíduos, podendo distorcer a realidade, como forma de mecanismo de defesa do ego). Muito mais do que a busca pelo acrescimento de número de leitores, temos como hipótese que tal estilo éticopatêmico pretende consolidar um coletivo integrado em torno do discurso polêmico em prol dos valores democráticos e pluralistas e contra ideologias ditas "neo-conservadoras" e extremistas. E, nesse discurso, se identificam os processos de dicotomização, de desqualificação do oponente e, em especial, de polarização.

Recordamos que o ambiente social e político após as eleições presidenciais de 2018 incrustou a polarização sociopolítica, o que, juntamente com a dicotomização e a desqualificação da voz do outro, permitiu que a polêmica fosse a principal modalidade argumentativa nas mídias. Como consequência, a maioria das colunas, blogs, vlogs, podcasts e demais gêneros presentes no domínio do jornalismo de opinião necessitaram fortalecer um estilo mais "personalista", por meio do esboço de determinados ethos 
ajustados a determinados coletivos. Em uma época do advento das fake news e, especialmente, da pós-verdade, o logos cede protagonismo para o ethos e o pathos. Os mecanismos retóricos, enunciativos e discursivos apresentados aqui não são exclusivos de um determinado grupo ideológico, mas sim estão disseminados entre os vários grupos polarizados, inclusive podendo chegar a altos graus de "incivilidade enunciativadiscursiva".

\section{Considerações finais: para além dos vínculos ético-patêmicos}

Depois de nossa trajetória teórico-metodológico-analítica, nos permitimos advogar pela relevância de análises retórico-textuais e enunciativo-discursivas nas atividades que abordem o ensino da linguagem e suas tecnologias, em particular em língua materna e línguas estrangeiras. É essencial que a problemática sobre os efeitos do ethos e do pathos na construção textual e discursiva seja discutida no curso de formação de professores e no Ensino Fundamental e Médio, respeitadas as peculiaridades de cada nível. Tais análises não devem estar apartadas das nuances articulatórias da materialidade linguística como demonstram nossos comentários de ordem textual, retórica, enunciativa e discursiva. Mais ainda, no campo da argumentação, é importante integrar a natureza do consenso e do dissenso na materialidade textual de várias esferas discursivas. Considerando esse contexto, a análise enunciativa e discursiva dirigida à compreensão da polêmica se torna primordial nos estudos linguísticos.

A série de indícios, apontados nesse trabalho nos possibilita formular a hipótese de que, para construir uma figura de representatividade midiática, social ou política, são relevantes os estudos sobre os mecanismos relacionados com o esboço de um ethos, conjugado com determinados efeitos patêmicos pretendidos, mas nunca definitivamente alcançados. Isso é crucial na era de crises democráticas em sociedades pluralistas, em que o dissenso caracteriza a maioria dos textos de dimensão argumentativa. Nesse sentido, os vínculos de natureza patêmica e a construção do ethos respondem à eclosão da polêmica na atualidade.

O fato de que, no campo político, a polêmica se traduza em termos de construção do ethos e de poder, tornando-se, assim, um ritual de posicionamento, chama a atenção para o fato de que a polêmica põe sempre em jogo imagens de si, que se inserem nas estratégias de promoção da própria pessoa. Mas esse aspecto de colocar em evidência seu domínio e sua superioridade não deve esconder as outras funções, essencialmente sociais, da polêmica [...].

Numa sociedade dividida, na qual o conflito de opiniões permanece como regra, caso se deseje preservar seu pluralismo e sua diversidade, a polêmica pública proporciona um meio de lutar por uma causa e de protestar contra o que é percebido como intolerável, de realizar reagrupamentos identitários, provocando 
trocas mais ou menos diretas com o adversário, e de gerenciar os desacordos, bastante profundos, sem lhes permitir degenerar em manifestações sociais e em violências fraticidas. É nesse sentido que ela constrói um espaço social [...] (AMOSSY, 2017, p. 216).

Conscientes de que o apresentado é uma ínfima parte do que ainda temos que refletir com relação à tríade sujeito, linguagem e sociedade, acreditamos ter contribuído com os estudos enunciativo-discursivos no labor de compreender melhor o mundo em que vivemos e os vínculos que estabelecemos na e pela linguagem, em especial, na atualidade plural que nos surpreende continuamente.

\section{REFERÊNCIAS}

ALMEIDA, A. C. A cabeça do brasileiro. Rio de Janeiro: Record, 2007.

AMOSSY, R. (org.). Imagens de si no discurso: a construção do ethos. São Paulo: Contexto, 2005.

AMOSSY, R. Apologia da polêmica. São Paulo: Contexto, 2017.

AUTHIER-REVUZ, J. Heterogeneidade mostrada e heterogeneidade constitutiva: elementos para uma abordagem do outro no discurso. In: AUTHIER-REVUZ, J. Entre a transparência e a opacidade: um estudo enunciativo do sentido. Porto Alegre: EDIPUCRS, 2004. p. 11-80.

BAUMAN, Z. Ser leve e líquido. In: BAUMAN, Z. Modernidade líquida. Rio de Janeiro: Jorge Zahar Editora, Prefácio, 2001. p. 07-22.

BENVENISTE, E. Problemas de Lingüística Geral II. 2. ed. São Paulo: Pontes, 2006.

BENVENISTE, E. Problemas de linguística geral I. 4. ed. Campinas: Pontes, 1995.

BRAIT, B. Ironia em perspectiva polifônica. 2. ed. Campinas: Editora da UNICAMP, 2008.

CHARAUDEAU, P. A conquista da opinião pública: como o discurso manipula as escolhas políticas. São Paulo: Contexto, 2016. 
CHARAUDEAU, P. A patemização na televisão como estratégia de autenticidade. In: MENDES, E.; MACHADO, I. L. (org.). As emoções no discurso. v. II. Campinas: Mercado das Letras, 2010. p. 23-56.

COSTA, S. R. Dicionário de gêneros textuais. Belo Horizonte: Autêntica, 2008.

DaMATTA, R. O que faz o brasil, Brasil? Rio de Janeiro: Rocco, 1986.

DISCINI, N. Corpo e estilo. São Paulo: Contexto, 2015.

FERNANDES, I. C. S. Qual é o refúgio da ironia? Considerações sobre os usos retóricos na construção de um lugar de interação. Estudos Linguísticos (São Paulo. 1978), São Paulo, v. 45, n. 3, p. 1276-1291, 2016.

FIORIN, L. A. Argumentação. São Paulo: Contexto, 2015.

FLORES, V. N.; TEIXEIRA, M. Introdução à Lingüística da Enunciação. São Paulo: Contexto, 2005.

GINZBURG, C. Mitos, emblemas, sinais: morfologia e história. São Paulo: Companhia das Letras, 1989.

MAINGUENEAU, D. A propósito do ethos. In: MOTTA, A. M.; SALGADO, L. (org.). Ethos Discursivo. 2. ed. São Paulo: Contexto, 2008.

PERELMAN, C.; OLBRECHTS-TYTECA, L. Tratado da argumentação: a nova retórica. 3. ed. São Paulo: Editora WMF Martins Fontes, 2014.

PLANTIN, C. Pathos. In: CHARAUdEAU, P.; MAINGUENEAU, D. Dicionário de Análise do Discurso. 2. ed. São Paulo: Contexto, 2006. p. 371-372.

PRATA. A. Coluna de Antonio Prata. Folha de S. Paulo. 2018-2019. Disponível em: https:// www1.folha.uol.com.br/colunas/antonioprata/. Acesso em: 15 set. 2019.

SANTI, P. L. R. Grandes temas atuais da Psicanálise. São Paulo: Casa do Saber, jul. /ago de 2019 (Curso online). 